\title{
Copy number variations of five $Y$ chromosome genes in donkeys
}

\author{
Haoyuan Han, Xiaocheng Zhao, Xiaoting Xia, Hong Chen, Chuzhao Lei, and Ruihua Dang \\ College of Animal Science and Technology, Northwest A\&F University, Yangling, Shaanxi 712100, China \\ Correspondence to: Chuzhao Lei (leichuzhao1118@126.com)
}

Received: 21 July 2017 - Revised: 11 September 2017 - Accepted: 14 September 2017 - Published: 18 October 2017

\begin{abstract}
In mammals, the $\mathrm{Y}$ chromosome plays a pivotal role in male sex determination and is essential for normal sperm production. A number of studies were conducted on $\mathrm{Y}$ chromosome genes of various species and identified single-copy and multi-copy genes. However, limited studies about donkey Y chromosome genes have been done. In this study, 263 male samples from 13 Chinese donkey breeds were collected to analyze the copy number variations (CNVs) of five $\mathrm{Y}$ chromosome genes using the quantitative PCR (qPCR) method. These five genes (cullin $4 \mathrm{~B}$ Y (CUL4BY), equus testis-specific transcript y1 (ETSTY1), equus testis-specific transcript y4 (ETSTY4), equus testis-specific transcript Y 5 (ETSTY5), and sex-determining region Y (SRY) were identified as multi-copy, whose median copy numbers (MCNs) were 5, 45, 2, and 2, and 13 with CNV ranges of 1-57, 1-227, $1-37,1-86$ and 1-152, respectively. The CNVs of these five genes were shared in different breeds. Compared to previous studies, the copy numbers of five genes showed some distinct consequences in this study. In particular, the well-known single-copy $S R Y$ gene showed CNVs in donkeys. Our results provided genetic variations of donkey Y chromosome genes.
\end{abstract}

\section{Introduction}

As a consequence of 230-300 million years of independent and non-recombining evolution, the majority (95\%) of the present-day $\mathrm{Y}$ chromosome is a male-specific region (MSY) that does not recombine with the X chromosome during meiosis to undergo homologous recombination (Graves, 1998; Quintana-Murci and Fellous, 2011). The MSY is enriched with multi-copy genes and copy number variations (CNVs) (Jobling, 2008; Skaletsky et al., 2003). CNVs are DNA segments of at least $50 \mathrm{bp}$ in size that vary in copy number among individuals of a species (Mills et al., 2011). In many cases, $\mathrm{CNV}$ has been linked to gene dosage, gene regulation, gene expression, and phenotype (Cahan et al., 2009; Henrichsen et al., 2009; Redon et al., 2006; Toft and Ross, 2010; Zhang et al., 2009).

$\mathrm{Y}$ chromosome is notoriously difficult to be sequenced because of its distinctive and structurally repetitive genomic landscapes. Thus, studies on CNV do not include an analysis of variation on the $\mathrm{Y}$ chromosome generally and only focus on a few Y-linked genes (Skaletsky et al., 2003). The testisspecific protein Y-encoded (TSPY) gene shows 20-76 copies and the CNVs have been found to be associated with semen quality and reproduction by regulating cell division in the process of spermatogenesis in men (Nickkholgh et al., 2010; Vodicka et al., 2007). The TSPY gene shows 37-200 copies on the bovine Y chromosome (BTAY) (Hamilton et al., 2009; Jakubiczka et al., 1993). The heat-shock transcription factor, Y-linked (HSFY) gene contains around 70 copies in bulls (Hamilton et al., 2011). The data from Yue et al. (2013) confirmed that the copy number of the preferentially expressed antigen in melanoma, Y-linked (PRAMEY) gene family was highly variable, ranging from 2 to 31 across 15 cattle breeds, and plays an important role in spermatogenesis.

The sex-determining region $\mathrm{Y}(S R Y)$ gene is known as the sex determination gene in mammalian development (Wilhelm et al., 2007). Thus, it is crucial to make clear of its CNV for a better understanding of $S R Y$ gene in donkeys. The testisspecific transcript Y (ETSTY) family is identified to consist of equine-specific genes (Paria et al., 2011); three of them (ETSTY1, ETSTY4, and ETSTY5) were chosen to analyze the CNVs in this study. The copy number of the cullin $4 \mathrm{~B} \mathrm{Y}$ $(C U L 4 B Y)$ gene has been detected in other species, such as 
cats and dogs (Murphy et al., 2006; Pearks Wilkerson et al., 2008). The CULABY gene was involved in this study in order to determine its copy numbers in donkeys. Copy numbers reveal the basic genetic and structural information of $\mathrm{Y}$ chromosome genes. Because of the lack of assembling $\mathrm{Y}$ chromosome sequences in donkeys, it is difficult to analyze the CNVs of those genes at donkey $\mathrm{Y}$ chromosome by resequencing. As such, the previous study determining copy numbers on donkey Y chromosome genes was limited.

Population and genetic sources of Chinese native donkeys are abundant. There are 24 Chinese native donkey breeds, and all of which have important functions in transportation and tourism as well as in the production of meat, skin, and milk. In particular, Dezhou donkeys are famous for their skins, which are great materials for donkey-hide gelatin, and Guanzhong donkeys are famous for improving the body size of small donkeys and producing large mules. However, until now, few analyses of CNVs of donkey Y-linked genes have been reported. In this study, the quantitative PCR (qPCR) method was performed to determine the copy number variations of five $\mathrm{Y}$ chromosome genes (CULABY, ETSTY1, ETSTY4, ETSTY5, and SRY) in 263 males from 13 Chinese donkey breeds, which would provide novel genetic variations of donkey genome.

\section{Materials and methods}

\subsection{Sampling}

Totaling 263 blood and ear tissue samples were obtained from 13 Chinese donkey breeds (Table 1). One additional female individual was used as female control in order to affirm the male specificity of the horse $\mathrm{Y}$ chromosome primers in donkeys. Genomic DNA was extracted from blood using a standard phenol-chloroform method (Sambrook and Russell, 2002). The DNA concentration was diluted to $20 \mathrm{ng} \mu \mathrm{L}^{-1}$ by ultrapure water and stored at $-20^{\circ}$.

\subsection{Primer design}

Primers of the beta-actin ACTB gene were designed using primer 5.0. The male-specific primers of five $\mathrm{Y}$ chromosome genes - CULABY, ETSTY1, ETSTY4, ETSTY5, and SRY were acquired from Paria et al. (2011). Details of primers are shown in Table 2. Two males, one female control, and one negative control were amplified using a routine PCR to identify the male specificity of five pairs of primers in donkeys. The PCR protocol was as follows: each $12.5 \mu \mathrm{L}$ reaction contained $20 \mathrm{ng}$ of pooled genomic DNA, $5 \mathrm{pM}$ each primer $\left(10\right.$ pmol $\left.\mu \mathrm{L}^{-1}\right), 6.25 \mu \mathrm{L}$ of $2 \times$ PCR mix buffer (including $0.375 \mathrm{U}$ Taq DNA polymerase, $2 \times$ PCR buffer, $18.75 \mu \mathrm{M}$ $\mathrm{MgCl}_{2}$ and $2.5 \mu \mathrm{M}$ dNTPs), and $4.75 \mu \mathrm{L}$ of distilled water. Thermocycling consisted of an initial denaturation at $95^{\circ} \mathrm{C}$ for $5 \mathrm{~min}$, followed by 35 cycles of at $94^{\circ} \mathrm{C}$ for $30 \mathrm{~s}$, at annealing temperature (Table 2) for $40 \mathrm{~s}$, at $72^{\circ} \mathrm{C}$ for $30 \mathrm{~s}$, and a final extension at $72{ }^{\circ} \mathrm{C}$ for $10 \mathrm{~min}$, before finally storing at $4^{\circ} \mathrm{C}$.

\subsection{Copy number variations (CNVs) estimation}

Standard curves and CNVs for each gene were measured by qPCR using Roche Lightcycler 480 system. qPCR was performed in plates with 96 wells, on which a calibrator, a negative control (distilled water), and diluted DNA (60, 40, 20, $10,5,2.5$, and $1.25 \mathrm{ng}_{\mu} \mathrm{L}^{-1}$ for standard curves) or testing samples ( $5 \mathrm{ng} \mu \mathrm{L}^{-1}$ for $\mathrm{CNV}$ estimation) were set up. qPCR reactions with DNA samples, calibrator, and negative control were run in triplicate. Each reaction contained $10 \mu \mathrm{L}$ of SYBR PCR master mix (TaKaRa, Dalian, China), $0.8 \mu \mathrm{L}$ of primers $\left(10 \mathrm{pmol} \mu \mathrm{L}^{-1}\right), 6.8 \mu \mathrm{L}$ of distilled water, and $1.6 \mu \mathrm{L}$ of DNA template $\left(5 \mathrm{ng} \mu \mathrm{L}^{-1}\right)$. The $\mathrm{qPCR}$ was run with a program of the following steps: predenaturation at $95^{\circ} \mathrm{C}$ for $10 \mathrm{~min}$, followed by 40 cycles of denaturation at $95^{\circ} \mathrm{C}$ for $5 \mathrm{~s}$ and annealing at appropriate temperature (Table 2) for $30 \mathrm{~s}$. A melting curve was then generated by taking fluorescent measurements every $0.11^{\circ} \mathrm{C}$ from 60 until $95^{\circ} \mathrm{C}$.

The cycle threshold $\left(C_{\mathrm{T}}\right)$ values generated from DNA of graded concentrations for reference ( $A C T B)$ and targeted genes (CULABY, ETSTY1, ETSTY4, ETSTY5, and SRY) were used to calculate the standard curves and their linear regression equations, the slopes of which were applied to measure primer efficiencies according to the equation $E=10^{(-1 / \text { slope })}$. Then, relying on additional three equations (listed as follows) described in Hamilton et al. (2009), the CNVs of CULABY, ETSTY1, ETSTY4, ETSTY5, and SRY were estimated. In the equations, the $C_{\mathrm{T}}$ values of the calibrator were determined by the average of all $C_{\mathrm{T}}$ values obtained in different plates for each gene, and $\Delta C_{\mathrm{T}}=C_{\mathrm{T}}$ of the calibrator $-C_{\mathrm{T}}$ of the test sample.

$$
\begin{aligned}
& \text { Copy number } r_{\text {calibrator }}=\frac{\left(E_{\text {reference }}\right)^{C_{\mathrm{T} \text { reference }}}}{\left(E_{\text {target }}\right)^{C_{\mathrm{T} \text { target }}}} \\
& \text { Ratio }=\frac{\left(E_{\text {target }}\right) \Delta C_{\mathrm{T} \text { target }}(\text { calibrator}- \text { sample })}{\left(E_{\text {reference }}\right) \Delta \mathrm{C}_{\mathrm{T} \text { reference }}(\text { calibrator }- \text { sample })} \\
& \text { Copy number } \\
& \quad \times(\text { ratiost sample }) \times 2 \\
& \times 2
\end{aligned}
$$

\subsection{Statistical analysis}

In order to minimize technical error and to obtain an accurate copy number $(\mathrm{CN})$ estimation, raw qPCR data showing a coefficient of variation $(\mathrm{CV})>1 \%$ between the duplicates were excluded from further analysis. The KolmogorovSmirnov and Shapiro-Wilk normality tests were used to analyze the normality of the CN data (Justel Peña and Zamar, 1997; Shapiro and Wilk, 1965). Box plot analysis of the CN data was conducted to detect the outliers in all the breeds as a whole. Multiple pair-wise comparisons of median copy 
Table 1. Sample information of 13 donkey breeds in China.

\begin{tabular}{llll}
\hline Breed & Abbreviation & Sample size & Collection location \\
\hline Qinghai donkey & QH & 30 & Minhe county, Qinghai Province \\
Gunsha donkey & GS & 25 & Yulin city, Shaanxi Province \\
Huaibei donkey & HL & 6 & Huaibei city, Anhui Province \\
Jiami donkey & JM & 19 & Mizhi county, Shaanxi Province \\
Liangzhou donkey & LZ & 11 & Wuwei city, Gansu Province \\
Kulun donkey & KL & 6 & Kulun county, Inner Mongolia Region \\
Qingyang donkey & QY & 16 & Qingyang city, Gansu Province \\
Guanzhong donkey & GU & 9 & Fufeng county, Shaanxi Province \\
Dezhou donkey & DZ & 60 & Dezhou city, Shandong Province \\
Biyang donkey & BY & 39 & Biyang county, Henan Province \\
Xiji donkey & XIJ & 16 & Xiji county, Ningxia Region \\
Xinjiang donkey & XJ & 21 & Yining city, Xinjiang Region \\
Changyuan donkey & CY & 5 & Changyuan county, Henan Province \\
\hline Total & & 263 & \\
\hline
\end{tabular}

Table 2. QPCR primer information for the $A C T B$ gene and five $\mathrm{Y}$ chromosome genes.

\begin{tabular}{|c|c|c|c|c|c|c|c|}
\hline Gene & & Primer F & Primer R & $T_{\mathrm{m}}\left({ }^{\circ}\right)$ & $\begin{array}{l}\text { Length } \\
\text { (bp) }\end{array}$ & $\begin{array}{l}\text { Accession } \\
\text { number }\end{array}$ & Reference \\
\hline \multirow{2}{*}{\multicolumn{2}{|c|}{$A C T B$}} & CACGCCTTTTGCTCAC & ACGGGCTTTGTCAC & \multirow[t]{2}{*}{$60-65$} & \multirow[t]{2}{*}{203} & \multirow[t]{2}{*}{ NC_009156 } & \multirow[t]{2}{*}{ this study } \\
\hline & & TTGTC & ACGAG & & & & \\
\hline CULABY & cullin $4 \mathrm{~B} \mathrm{Y}$ & $\begin{array}{l}\text { TGTGGGGTTCGTGTG } \\
\text { AAATA }\end{array}$ & $\begin{array}{l}\text { CAAGGATCGCTGGGT } \\
\text { CTTAC }\end{array}$ & 60 & 172 & EU687546 & $\begin{array}{l}\text { Paria et al. } \\
\text { (2011) }\end{array}$ \\
\hline ETSTY1 & $\begin{array}{l}\text { equus testis- } \\
\text { specific transcript } \\
\text { Y1 }\end{array}$ & $\begin{array}{l}\text { GACGGACGACCTTGT } \\
\text { GTTTT }\end{array}$ & $\begin{array}{l}\text { CTAGTGGCGAGTCCT } \\
\text { TTTGG }\end{array}$ & 63 & 234 & EU687549 & $\begin{array}{l}\text { Paria et al. } \\
\text { (2011) }\end{array}$ \\
\hline ETSTY4 & $\begin{array}{l}\text { equus testis- } \\
\text { specific transcript } \\
\text { Y4 }\end{array}$ & $\begin{array}{l}\text { GCGTCTGTGCAGATG } \\
\text { TGTCT }\end{array}$ & $\begin{array}{l}\text { GCTCATGCAGTCAAA } \\
\text { CAGGA }\end{array}$ & 65 & 175 & EU687552 & $\begin{array}{l}\text { Paria et al. } \\
(2011)\end{array}$ \\
\hline ETSTY5 & $\begin{array}{l}\text { equus testis- } \\
\text { specific transcript } \\
\text { Y5 }\end{array}$ & $\begin{array}{l}\text { CAAAACCAAGAGGA } \\
\text { GGACCA }\end{array}$ & $\begin{array}{l}\text { CTCCAGAGGCAGGT } \\
\text { ACTTCG }\end{array}$ & 65 & 210 & EU687553 & $\begin{array}{l}\text { Paria et al. } \\
\text { (2011) }\end{array}$ \\
\hline SRY & $\begin{array}{l}\text { sex-determining } \\
\text { region Y }\end{array}$ & $\begin{array}{l}\text { CCAACGCTTTATCTT } \\
\text { CGCA }\end{array}$ & $\begin{array}{l}\text { CCATTTCCTCTTGTT } \\
\text { TCACTCC }\end{array}$ & 63 & 203 & NM_001081810 & this study \\
\hline
\end{tabular}

number (MCN) between breeds were analyzed using a nonparametric Mann-Whitney $U$ test (Mann and Whitney, 1947) with a Bonferroni correction (Dunn, 1961).

\section{Results and discussion}

\subsection{Male specificity of primers}

The donkey $\mathrm{Y}$ chromosome sequence is not available. In an investigation of the equid Y chromosome, the horse and donkey MSY gene contents were compared. Comparative analysis of horse and donkey MSY revealed that the $C U L 4 B Y$, ETSTY1, ETSTY4, ETSTY5, and SRY genes are shared in the genome of these two species; the sequence identity was 95$100 \%$ between the homologous horse and donkey transcripts according to Paria et al. (2011), who also verified that the primers for these five genes were male-specific in both horses and donkeys. In this study, the results of DNA fragments amplified with two males, one female control, and one negative control are shown in Fig. 1; $A C T B$ showed a single band of expected size in male and female samples. The ETSTY4 and $S R Y$ genes displayed a male-specific band. The $C U L A B Y, E T$ $S T Y 1$, and ETSTY5 genes showed different sized fragments in females. However, the amplified band for each gene was specific and correctly sized in males; thus, it is reasonable to use the primers for our CNVs analysis. 

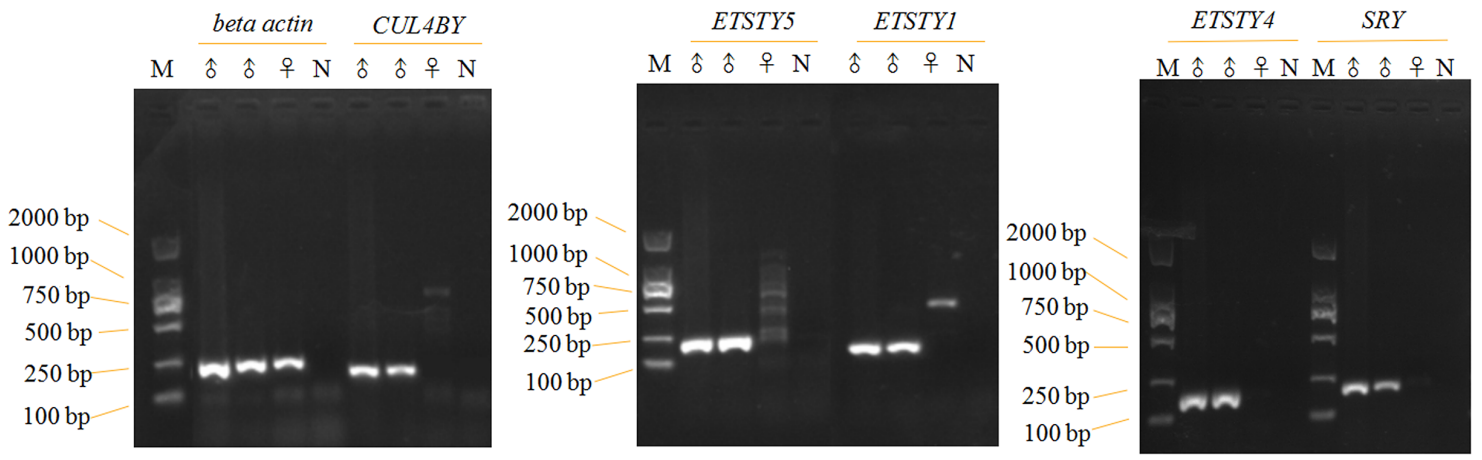

Figure 1. Gel electrophoresis of PCR products of six donkey genes. The primers of these five Y-linked genes amplified male-specific bands with expected fragment size labeled above the band. M: 2 kb DNA ladder; $\widehat{\partial}$ : male donkey genomic DNA; : female donkey genomic DNA; $\mathrm{N}$ : negative control (distilled water).

Table 3. Correlation coefficient of standard curve and primer efficiency for $A C T B$ and five $\mathrm{Y}$ chromosome genes.

\begin{tabular}{lrr}
\hline Gene & $\begin{array}{r}\text { Correlation } \\
\text { coefficient }\left(R^{2}\right)\end{array}$ & $\begin{array}{r}\text { Primer } \\
\text { efficiency }(E)\end{array}$ \\
\hline ACTB & 0.9995 & 2.14 \\
ETSTY1 & 0.9913 & 1.90 \\
SRY & 0.9933 & 1.93 \\
ACTB & 0.9973 & 1.90 \\
ETSTY4 & 0.9976 & 2.01 \\
ETSTY5 & 0.9941 & 1.97 \\
ACTB & 0.9915 & 1.92 \\
CULABY & 0.9961 & 1.98 \\
\hline
\end{tabular}

\subsection{The CNVs of five $\mathrm{Y}$ chromosome genes in donkeys}

According to the linear regression equations of standard curves and the equation $E=10^{(-1 / \text { slope })}$, correlation coefficients $\left(R^{2}\right)$ were all higher than 0.99 and primer efficiencies (E) were higher than 1.90 for the ACTB, CULABY, ETSTY1, ETSTY4, ETSTY5, and SRY genes (Table 3). In total, the CNVs of 263 males from 13 Chinese donkey breeds were estimated. The CULABY, ETSTY1, ETSTY4, ETSTY5, and SRY were all multi-copy with median copy numbers (MCNs) of 5, $45,2,2$, and 13 , respectively. The CNVs ranges were $1-57$, $1-227,1-37,1-86$, and 1-152, respectively (Table 4). Based on Kolmogorov-Smirnov and Shapiro-Wilk normality tests, the copy numbers (CNs) of the five donkey Y chromosome genes did not fit the normal distribution in Chinese horses $(P<0.0001)$. Box plot analyses of the CNs data revealed that approximately $10-15$ individuals $(4-6 \%)$ were outliers that had significantly higher $\mathrm{CN}$ for each gene (Fig. 2).

For the CULABY gene, the CNVs ranged from 1 to 57 with MCNs of 2-9 in 13 donkey breeds, while Guanzhong (GZ) donkeys had the highest MCN of 9 (Table 4). Dezhou donkeys showed significantly different $\mathrm{MCN}$ from nine other breeds for the CULABY gene (Table S1 in the Supplement).

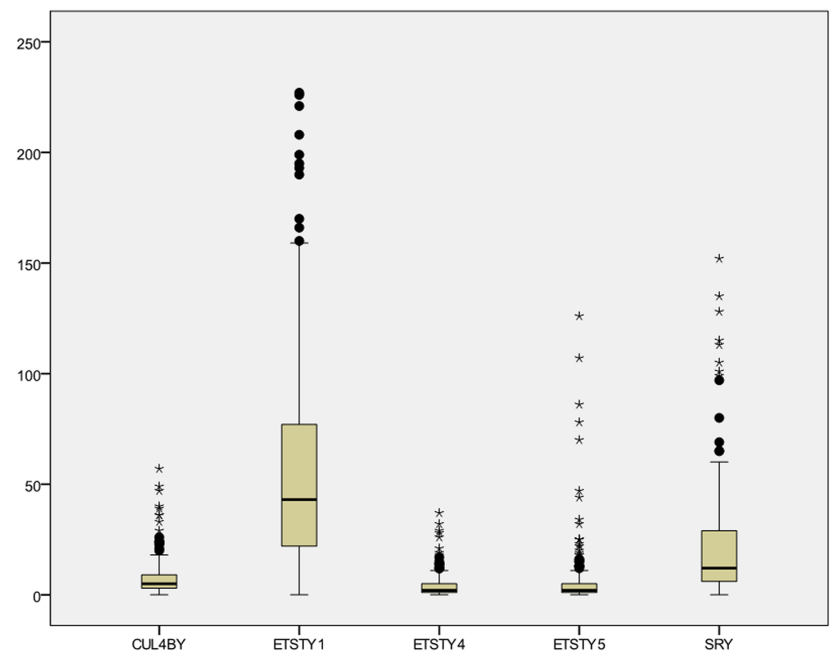

Figure 2. Box plot analysis of five genes' CNs in donkeys. The outliers are indicated by a solid circle or an asterisk (extremely high $\mathrm{CN}$ ), which include 10-15 donkeys in all breeds for five Y chromosome genes.

Similarly, the highly amplified CUL4BY gene has been identified in the cats and dogs. (Murphy et al., 2006; Pearks Wilkerson et al., 2008). The horse CULABY showed intermediate expression being transcribed in testis, heart, spleen, and kidney (Paria et al., 2011); thus, the horse CULABY might be related to testis and male germ cell proliferation (Petroski and Deshaies, 2005). Considering the close relationship of donkeys and horses, we assumed that the donkey CULABY had an important function in male fertility.

The ETSTY family is novel and equid-specific, the orthologue of which is not found in non-equid species. The range of CNVs of the ETSTY1 gene was 1-227, with the MCNs varying from 12 (GZ donkey) to 99 (Changyuan donkey) in different breeds (Table 4), indicating that the ETSTY1 gene was a largely amplified gene with multiple copies. GZ donkeys exhibited significant difference of MCNs from 10 other 
Table 4. Copy number variations of five Y chromosome genes in donkeys.

\begin{tabular}{|c|c|c|c|c|c|c|}
\hline \multirow[t]{2}{*}{ Breed } & \multirow[t]{2}{*}{ No. of samples } & \multicolumn{5}{|c|}{ Median copy number (copy number variation) } \\
\hline & & $C U L A B Y$ & ETSTY1 & ETSTY4 & ETSTY5 & $S R Y$ \\
\hline QH & 30 & $3(1-14)$ & $64(11-166)$ & $3(1-14)$ & $2(1-20)$ & $12(1-42)$ \\
\hline GS & 25 & $2(1-5)$ & $19(4-90)$ & $1(1-21)$ & $1(1-18)$ & $4(1-33)$ \\
\hline HL & 6 & $2(1-3)$ & $17(14-59)$ & $1(1-2)$ & $2(1-10)$ & $10(6-38)$ \\
\hline JM & 19 & $7(4-49)$ & $61(24-226)$ & $5(2-8)$ & $25(3-86)$ & $63(11-152)$ \\
\hline $\mathrm{LZ}$ & 11 & $4(2-6)$ & $65(25-195)$ & $1(1-7)$ & $1(1-10)$ & $8(7-21)$ \\
\hline KL & 6 & $2(1-4)$ & $51(16-94)$ & 1 & $1(1-5)$ & $2(1-11)$ \\
\hline QY & 16 & $4(1-11)$ & $70(23-193)$ & $3(1-6)$ & $5(1-18)$ & $12(4-59)$ \\
\hline GZ & 9 & $9(4-13)$ & $12(1-44)$ & $2(2-19)$ & $3(1-5)$ & $30(4-97)$ \\
\hline $\mathrm{DZ}$ & 60 & $8(2-47)$ & $29(5-142)$ & $2(1-37)$ & $2(1-31)$ & $7(1-101)$ \\
\hline BY & 39 & $8(2-57)$ & $57(2-227)$ & $4(1-29)$ & $2(1-12)$ & $33(1-65)$ \\
\hline GY & 16 & $3(2-11)$ & $55(32-162)$ & $2(1-3)$ & $2(1-9)$ & $17(6-34)$ \\
\hline XJ & 21 & $2(1-36)$ & $50(6-102)$ & $1(1-5)$ & $3(1-16)$ & $11(4-51)$ \\
\hline \multirow[t]{2}{*}{$\mathrm{CY}$} & 5 & $3(3-5)$ & $99(73-163)$ & $3(2-4)$ & 1 & $13(11-20)$ \\
\hline & 263 & $5(1-57)$ & $45(1-227)$ & $2(1-37)$ & $2(1-86)$ & $13(1-152)$ \\
\hline
\end{tabular}

Abbreviations: QH, Qinghai donkey; GS, Gunsha donkey; HL, Huaibei donkey; JM, Jiami donkey; LZ, Liangzhou donkey; KL, Kulun donkey; QY, Qingyang donkey; GU, Guanzhong donkey; DZ, Dezhou donkey; BY, Biyang donkey; XIJ, Xiji donkey; XJ, Xinjiang donkey; CY, Chuangyuan donkey.

breeds (Table S2). For the ETSTY4 gene, Jiami (JM) donkeys possessed the highest MCN of 5 (Table 4). The MCN of JM donkeys was significantly different from that of 10 other breeds (Table S3). The highest MCN of the ETSTY5 gene was found in the JM breed (MCN of 25), while the MCNs only varied from 1 to 5 in 12 other breeds (Table 4). The comparisons of the MCN of the ETSTY5 gene showed that JM donkeys exhibited different MCNs from 12 other breeds (Table S4). ETSTY1, ETSTY4, and ETSTY5 showed multiple copies according to cDNA FISH (Paria et al., 2011), the CNVs of which were confirmed in this study. These genes were expressed exclusively in testis of horses (Paria et al., 2011), but the expression profile remained uncertain in donkeys. More transcriptional analysis of donkeys should be conducted. It is hypothesized that these novel equine transcripts encode novel proteins or may be non-coding transcription units (Hughes et al., 2010; Skaletsky et al., 2003); this needs further verification.

The $S R Y$ gene has the function in sex determination at early stages of mammalian embryonic development (Wilhelm et al., 2007). From a functional standpoint it is expected that the $S R Y$ gene would commonly be found in multiple copies to buffer against mutations in any single copy, thus maintaining enough intact copies to perform the gene's normal function (Lahn et al., 2001). SRY has been assumed to be present as multiple functional copies in rabbits (Geraldes and Ferrand, 2006), rats (Turner et al., 2007), and cats (Pearks Wilkerson et al., 2008) Y chromosomes. Our results further supported the $S R Y$ function assumption that $S R Y$ was found as a multi-copy gene in donkeys with an MCN of 13 and a variable CNV range (1-152). The MCN of $S R Y$ was highest in JM donkeys (63) and lowest in KL donkeys (2) (Table 4).
The MCNs of Gunsha, JM and Kulun donkeys showed significantly different MCN from 10 breeds (Table S5). However, $S R Y$ is considered as a single-copy gene in the human and mouse Y chromosome sequences (Hughes et al., 2010; Skaletsky et al., 2003; Toure et al., 2004). In horses, it remains disputed whether $S R Y$ was single-copied by cDNA FISH (Paria et al., 2011). Therefore, more studies, including gene copy number analysis and detailed expression profiling, will be needed to determine the homology between the two $\mathrm{Y}$ chromosomes in more detail.

\section{Conclusions}

The copy numbers of five donkey genes on $\mathrm{Y}$ chromosome were determined in current study. The CULABY, ETSTY1, ETSTY4, ETSTY5, and SRY genes are multi-copy and have MCNs of 5, 45, 2, 2, and 13 with CNV ranges of $1-57$, $1-227,1-37,1-86$ and $1-152$, respectively. We first investigated the copy numbers of donkey Y chromosome genes, providing basic genetic information for future studies in donkeys.

Data availability. The original data of the paper are available upon request from the corresponding author.

The Supplement related to this article is available online at https://doi.org/10.5194/aab-60-391-2017-supplement. 
Author contributions. HH, CL, and RD designed this project; $\mathrm{XZ}$ and XX collected blood from animals; HH performed experiments in the laboratory; and $\mathrm{HH}$ wrote the paper.

Competing interests. The authors declare that they have no conflict of interest.

Acknowledgements. This work was supported by National Natural Science Foundation of China (31072001, 31272399, 81270439).

Edited by: Steffen Maak

Reviewed by: two anonymous referees

\section{References}

Cahan, P., Li Y., Izumi, M., and Graubert, T. A.: The impact of copy number variation on local gene expression in mouse hematopoietic stem and progenitor cells, Nat. Genet., 41, 430-437, 2009.

Dunn, O. J.: Multiple comparisons among means, J. Am. Stat. Assoc., 56, 52-64, 1961.

Geraldes, A. and Ferrand, N.: A 7-bp insertion in the 39 untranslated region suggests the duplication and concerted evolution of the rabbit SRY gene, Genetics, selection, evolution, Genetics, selection, evolution: GSE, 38, 313-320, 2006.

Graves, J. A.: Evolution of the mammalian Y chromosome and sexdetermining genes, J. Exp. Zool., 281, 472-481, 1998.

Hamilton, C. K., Favetta, L. A., Di Meo, G. P., Floriot, S., Perucatti, A., Peippo, J., Kantanen, J., Eggen, A., Iannuzzi, L., and King, W. A.: Copy number variation of testis-specific protein, Y-encoded (TSPY) in 14 different breeds of cattle (Bos taurus), Sex. Dev., 3, 205-213, 2009.

Hamilton, C. K., Revay, T., Domander, R., Favetta, L. A., and Allan King, W. A.: large expansion of the HSFY gene family in cattle shows dispersion across Yq and testis-specific expression, PLoS One, 6, e17790, https://doi.org/10.1371/journal.pone.0017790, 2011.

Henrichsen, C. N., Chaignat, E., and Reymond, A.: Copy number variants, diseases and gene expression, Hum. Mol. Genet., 18, R1-8, 2009.

Hughes, J. F., Skaletsky, H., Pyntikova, T., Graves, T. A., van Daalen, S. K., Minx, P. J., Fulton, R. S., McGrath, S. D., Locke, D. P., Friedman, C., Trask, B. J., Mardis, E. R., Warren, W. C., Repping, S., Rozen, S., Wilson, R. K., and Page, D. C.: Chimpanzee and human $\mathrm{Y}$ chromosomes are remarkably divergent in structure and gene content, Nature, 463, 536-539, 2010.

Jakubiczka, S., Schnieders, F., and Schmidtke, J.: A bovine homologue of the human TSPY gene, Genomics, 17, 732-735, 1993.

Jobling, M. A.: Copy number variation on the human Y chromosome, Cytogenet. Genome Res., 123, 253-262, 2008.

Justel Peña, A. D. and Zamar, R.: A multivariate KolmogorovSmirnov test of goodness of fit, Stat. Probab. Lett., 35, 251-259, 1997.

Lahn, B. T., Pearson, N. M., and Jegalian, K.: The human Y chromosome, in the light of evolution, Nat. Rev. Genet., 2, 207-216. 2001.
Mann, H. B. and Whitney, D. R.: On a test of whether one of two random variables is stochastically larger than the other, Ann. Math. Stat., 18, 50-60, 1947.

Mills, R. E., Walter, K., Stewart, C., Handsaker, R. E., Chen, K., Alkan, C., Abyzov, A., Yoon, S. C., Ye, K., Cheetham, R. K., Chinwalla, A., Conrad, D. F., Fu, Y., Grubert, F., Hajirasouliha, I., Hormozdiari, F., Iakoucheva, L. M., Iqbal, Z., Kang, S., Kidd, J. M., Konkel, M. K., Korn, J., Khurana, E., Kural, D., Lam, H. Y., Leng, J., Li, R., Li, Y., Lin, C., Luo, R., Mu, X. J., Nemesh, J., Peckham, H. E., Rausch, T., Scally, A., Shi, X., Stromberg, M. P., Stutz, A. M., Urban, A. E., Walker, J. A., Wu, J., Zhang, Y., Zhang, Z. D., Batzer, M. A., Ding, L., Marth, G. T., McVean, G., Sebat, J., Snyder, M., Wang, J., Ye, K., Eichler, E. E., Gerstein, M. B., Hurles, M. E., Lee, C., McCarroll, S. A., Korbel, J. O., and 1000 Genomes Project: Mapping copy number variation by population-scale genome sequencing, Nature, 470, 59-65, 2011.

Murphy, W. J., Pearks Wilkerson, A. J., Raudsepp, T., Agarwala, R., Schaffer, A. A., Stanyon, R., and Chowdhary, B. P.: Novel gene acquisitionon carnivore Y chromosomes, PLoS genet., 2, e43, https://doi.org/10.1371/journal.pgen.0020043, 2006.

Nickkholgh, B., Noordam, M. J., Hovingh, S. E., van Pelt, A. M., van der Veen, F., and Repping, S.: Y chromosome TSPY copy numbers and semen quality, Fertil. Steril., 94, 1744-1747, 2010.

Paria, N., Raudsepp, T., Wilkerson, A. J. P., O'Brien, P. C. M., Ferguson-Smith, M. A., Love, C. C., Arnold, C., Rakestraw, P., Murphy, W. J., and Chowdhary, B. P.: A gene catalogue of the euchromatic male-specific region of the horse $\mathrm{Y}$ chromosome: comparison with human and other mammals, PLoS One, 6, e21374, https://doi.org/10.1371/journal.pone.0021374, 2011.

Pearks Wilkerson, A. J, Raudsepp, T., Graves, T., Albracht, D., Warren, W., Chowdharya, B. P., Skowa, L. C., and Murphy, W. J.: Gene discovery and comparative analysis of X-degenerate genes from the domestic cat Y chromosome, Genomics, 92, 329-338, 2008.

Petroski, M. D. and Deshaies, R. J.: Function and regulation of cullin-RING ubiquitin ligases, Nat. Rev. Mol. Cell Biol., 6, 920, 2005.

Quintana-Murci, L. and Fellous, M.: The human Y chromosome: The biological role of a "functional wasteland", J. Biomed. Biotechnol., 1, 18-24, 2001.

Redon, R., Ishikawa, S., Fitch, K. R., Feuk, L., Perry, G. H., Daniel Andrews, T., Fiegler, H., Shapero, M. H., Carson, A. R., Chen, W., Kyung Cho, E., Dallaire, S., Freeman, J. L., González, J. R., Gratacòs, M., Huang, J., Kalaitzopoulos, D., Komura, D., MacDonald, J. R., Marshall, C. R., Mei, R., Montgomery, L., Nishimura, K., Okamura, K., Shen, F., Somerville, M. J., Tchinda, J., Valsesia, A., Woodwark, C., Yang, F., Zhang, J., Zerjal, T., Zhang, J., Armengol, L., Conrad, D. F., Estivill, X., Tyler-Smith, C., Carter, N. P., Aburatani, H., Lee, C., Jones, K. W., Scherer, S. W., and Hurles, M. E.: Global variation in copy number in the human genome, Nature, 444, 444-454, 2006.

Sambrook, J. and Russell, D. W.: Molecular cloning: A laboratory manual, translated by: Huang, P. T., Beijing: Science Press; Beijing, China, 2002.

Shapiro, S. S. and Wilk, M. B.: An analysis of variance test for normality (complete samples), Biometrika, 52, 591-611, 1965.

Skaletsky, H., Kuroda-Kawaguchi, T., Minx, P. J., Cordum, H. S., Hillier, L., Brown, L. G., Repping, S., Pyntikova, T., Ali, J., Bieri, T., Chinwalla, A., Delehaunty, A., Delehaunty, K., Du, H., 
Fewell, G., Fulton, L., Fulton, R., Graves, T., Hou, S. F., Latrielle, P., Leonard, S., Mardis, E., Maupin, R., McPherson, J., Miner, T., Nash, W., Nguyen, C., Ozersky, P., Pepin, K., Rock, S., Rohlfing, T., Scott, K., Schultz, B., Strong, C., Tin-Wollam, A., Yang, S. P., Waterston, R. H., Wilson, R. K., Rozen, S., and Page, D. C.: The male-specific region of the human $\mathrm{Y}$ chromosome is a mosaic of discrete sequence classes, Nature, 423, 825-837, 2003.

Toft, M. and Ross, O. A.: Copy number variation in Parkinson's disease, Genome Medicine, 2, p. 62, 2010.

Toure, A., Szot, M., Mahadevaiah, S. K., Rattigan, A., Ojarikre, O. A., and Burgoyne, P. S.: A new deletion of the mouse Y chromosome long arm associated with the loss of Ssty expression, abnormal sperm development and sterility, Genetics, 166, 901912, 2004

Turner, M. E., Martin, C., Martins, A. S., Dunmire, J., Farkas, J., Ely, D. L., and Milsted, A.: Genomic and expression analysis of multiple Sry loci from a single Rattus norvegicus Y chromosome, BMC Genet., 8, p. 11, 2007.
Vodicka, R., Vrtel, R., Dusek, L., Singh, A.R., Krizova, K., Svacinova, V., Horinova, V., Dostal, J., Oborna, I., Brezinova, J., Sobek, A., and Santavy, J.: TSPY gene copy number as a potential new risk factor for male infertility, Reprod. Biomed. Online, 14, 579-587, 2007.

Wilhelm, D., Palmer, S., and Koopman, P.: Sex determination and gonadal development in mammals, Physiol. Rev., 87, 1-28, 2007.

Yue, X. P., Chang, T. C., DeJarnette, J. M., Marshall, C. E., Lei, C. Z., and Liu, W. S.: Copy number variation of PRAMEY across breeds and its association with male fertility in Holstein sires, J. Dairy Sci., 96, 8024-8034, 2013.

Zhang, F., Gu, W., Hurles, M. E., and Lupski, J. R.: Copy number variation in human health, disease, and evolution, Annu. Rev. Genomics Hum. Genet., 10, 451-481, 2009. 